\title{
Radiation data wanted
}

SIR - In 1975, the International Commission on Radiological Protection (ICRP) published its Publication 23, the Report of the Task Group on Reference Man. Publication 23 is about 15 years out of date, because the references cited end around 1970. At its 1984 meeting, ICRP approved the formation of a new task group to revise and update this publication, with completion expected in about three years.

The revision will include more emphasis on variations due to age, sex and other individual differences in anatomical and physiological data and in the gross and elemental composition of tissues. The emphasis in Publication 23 is on data for radiation workers, and the new emphasis reflects the fact that radiation doses to the whole population are of increasing interest to ICRP and national bodies interested in radiation protection.

The purpose of this letter is to solicit information from users of ICRP Publication 23 , incuding workers in the medical and biological sciences outside radiation protection who have used the document. In order that the revised document may be accurate and complete, it is important that we get advice from as many users as possible. The present task group would appreciate hearing about any errors, omissions of important information or shortcomings in Publication 23 or of relevant new data not included.

Please write to the task group chairman at the address below.

\section{C.R. RICHMOND} (Chairman)

Task Group on Revision of

Reference Man,

Oak Ridge National Laboratory,

$P O$ Box $X$,

Oak Ridge, Tennessee 37831, USA

\section{Creationism}

SIR - As our organization, the Association for the Protection of Evolution (APE), has been accused of misrepresentation and an ethical lapse by Professor E.H. Andrews in his response (Nature 312, $396 ; 1984)$ to our report of the Biblical Creation Society (BCS) open day (Nature $311,703 ; 1984)$, we feel obliged to reply. First, if Professor Andrews claims to be a theist, why is he engaged on a project involving natural theological argument and the acquisition of empirical evidence from the natural world for the existence and putative activities of a God - a paradigmatically deistic position implicitly shared by all creationists whether they understand the meaning of the word or not? Second, Mr Malcolm Bowden (for it was he) has on several occasions castigated BCS for its dangerous backsliding tendencies towards the position of theistic evolutionism. Third, Andrews waxes indignant at the suggestion that he has criticized US "scientific" creationism; we need only quote from his seminal article in the BCS "journal", Biblical Creation (vol.5, no.16) to show that he has been criticizing US creationism for some time. In this, the first "Biblical Creation Lecture", he writes "the American branch of creationist movement (sic) has therefore attempted to develop a scientific creationism that has no religious content". He goes on to say that such creationism involves "a number of very real dangers and problems", is "a-Christian" and "devoid of biblical content". His lecture (which we have on tape) merely amplified his previously published criticisms.

Chris Darnborough was introduced as doing research on genetic engineering and evinced an adequate knowledge of modern genetics, unlike all the other creationists we have so far encountered. APE made a theologically acceptable in pectoris decision to elevate Darnborough to the honorary position of BCS's top geneticist in default of any other candidates. The title of his lecture was, after all, "Genes created but EVOLVING" and he did have to apologize to his audience in advance in case they mistook the bulk of his lecture as putting the evolutionist view.

As for APE's "ethical lapse", in reporting Dr Gower, he did indeed state his belief that faults in the perfection of the "design" of the human olfactory organ are due to the effects of the fall of Adam and/or the work of the Devil. Whether he believes this enthusiastically or unenthusiastically is a matter of judgement. Our opinion was the latter. In any event, APE explicitly informed the organizers of the conference that it would be reporting their deliberations for the scientific press.

Michael E. Howgate Department of Zoology,

University College London, Gower Street, London WCIE 6BT, UK

Alan J. LEWIS

Cybernetics, Brunel University, Uxbridge UB8 $3 P H, U K$

SIR - The article "Louisiana law thrown out"' (24 January, p.257), described the US court system's rejection of a law that would have required teachers to include "creation-science" along with "evolutionscience". The law defined "creationscience" to be "the scientific evidence for creation, and inferences from those scientific evidences". This law required that students be given crucial data, even if they support a theory contrary to the beliefs of the teacher. Teachers who believe the creation account of origins would be required to include the evidence for evolution, just as the proponents of evolution would be required to discuss the evidence for creation. The rejection of this law en- courages censorship of data about origins.

The inherent religious nature of all versions of origins must not be minimized. It is true that the creation account of origins is consistent with some "theistic religious views". The theory of evolution is consistent with the tenets of non-theistic religions as well as the tenets of the "main-line" and "liberal" churches. All views of origins support someone's religion: there is no religiously neutral theory of origins.

Students have a right to know that the lack of intermediate fossils discredits Darwin's theory of evolution. Students should also be informed that the modern belief in molecular evolution is held in spite of the fact that real observations require the rejection of spontaneous generation. The causes behind the shift in opinion away from creation in the 1850 s should be reviewed and discussed with students. The citizens of Louisiana wanted to ensure that crucial data, such as the gaps in the fossils and the Law of Biogenesis, will be part of public school curricula.

The students must be able freely to form their opinions without the fear that critical data have been withheld. It is sad that one federal court and the American Civil Liberties Union seem to disagree.

RUSSELl T. ARNDTS

Chemistry Department,

St Cloud State University,

St Cloud, Minnesota 56301, USA

\section{Missing mass}

SIR - I would like to make only a point of general scientific method in reply to your reviewer who found "glaring errors and omissions" in my book The Hidden Universe (Nature 24 January, p.329).

The book attempts to explain the subject of "missing mass" to the layman. Surely the significant point about this subject is the small but increasing body of observational evidence that has now brought sceptical astronomers round to believe in this phenomenon. The point is not the plethora of mythical particles, or other agencies, which can all too easily be advanced to fill up extragalactic space. Precisely because we know so little about the phenomenon, it is of course at present hard to test out the presence there of axions, heavenly chariots or discarded bandwagons. That being so, economy of effort alone directs our attention first to those candidates that are either known to exist, such as neutrinos, or at least lead to some testable predictions. Supersymmetry and GUT [Grand Unified Theory] particles may be appealing to some, while reminding others of epicycles. For the moment, GUTs have fluffed their first proton-decay test, and the fact that they contain 21 readjustable free parameters could be held to lessen rather than add to their appeal in the context of missing mass. MICHAEL DISNEY

Department of Applied Mathematics

\& Astronomy, University College, PO Box 78, Cardiff CFI IXL, UK 